\title{
ISAÍAS 7:14 E ZACARIAS 12:10. UMA ANÁLISE DAS TRADUÇÕES DE DUAS PASSAGENS MESSIÂNICAS DO ANTIGO TESTAMENTO À LUZ DAS SUAS COORDENADAS ESPAÇO-TEMPORAIS
}

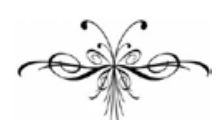

MARCELO RAUPP

Resumo: Este artigo é uma análise comparativa das traduções propostas por sete versões da Bíblia em português, tomando como ponto de partida as coordenadas espaçotemporais de dois acontecimentos discursivos do Antigo Testamento, expressos em Isaías 7:14 (contrastado com Mateus 1:23) e em Zacarias 12:10, que os cristãos mais têm utilizado para provar uma potencial messianidade de Jesus de Nazaré.

Palavras-chave: Exegese. Viés teológico. Tradução da Bíblia.

\begin{abstract}
This is a comparative analysis of the translations of seven versions of the Bible into Portuguese. It takes as its starting point the space-time coordinates of two discursive events of the Old Testament found in Isaiah 7:14 (examined along Mathew 1:23) and Zachariah 12:10 of which Christians have most frequently made use in order to prove a potential messiahship of Jesus of Nazareth.
\end{abstract}

Keywords: Exegesis. Theological point of view. Bible translation. 


\section{Considerações preliminares}

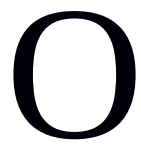
texto religioso hoje conhecido pelo nome de Bíblia é uma coletânea de escritos muito antigos, resultantes da longa experiência religiosa dos judeus e dos primeiros cristãos. Estima-se que os livros foram escritos ao longo de aproximadamente um milênio e meio, em diferentes regiões de Israel e em contextos culturais variados. Tendo em vista o seu surgimento no meio religioso, a Bíblia tem sido utilizada como texto fundador de diversas religiões, em especial aquelas de matrizes judaicas e cristãs.

Uma doutrina que tem predominado tanto entre judeus quanto entre cristãos é a de que a Divindade enviaria ao mundo um misterioso personagem para expiar os pecados dos seres humanos, personagem esse que o chamado Antigo Testamento denomina de Messias. Os cristãos acreditam que esse personagem já veio e que ele é Jesus de Nazaré, ao passo que há uma tendência entre os judeus tradicionais de rejeitar essa ideia, assim como também de rejeitar a coletânea de textos que discorrem sobre a vida e o ministério de Jesus, coletânea essa que os cristãos denominam de Novo Testamento (doravante NT), originalmente escrito em grego. Assim, a Bíblia utilizada pelo Judaísmo tradicional possui apenas a parte que os cristãos chamam de Antigo Testamento (doravante AT), originalmente escrito em hebraico. Como forma de provar uma potencial messianidade de Jesus, os cristãos têm se valido no decorrer dos séculos de várias passagens proféticas registradas nas escrituras hebraicas (o AT dos cristãos), no intuito de comprovar que tais passagens teriam se cumprido na pessoa de Cristo. Dois exemplos bem proeminentes disso são Isaías 7:14 e Zacarias 12:10.

Com base no exposto, pretendemos neste artigo fazer uma análise comparativa das traduções propostas por sete versões da Bíblia em português, tomando como ponto de partida da análise as coordenadas espaço-temporais em que as referidas passagens estão inseridas. Nosso objetivo é investigar se as alegações cristãs procedem em alguma medida, já que tanto o livro de Isaías quanto o de Zacarias são acontecimentos discursivos que vieram à luz em situações históricas concretas e específicas, bem antes do surgimento do Cristianismo. Nas seções 2, 3 e 4, a seguir, constam o nosso embasamento teórico, que tanto fornece subsídios conceituais quanto serve de preparação para a seção 5 , que traz a análise propriamente dita das duas passagens bíblicas que estamos nos propondo a analisar.

No que diz respeito ao corpus, procuramos considerar as versões mais bem conceituadas feitas pelas duas principais comunidades religiosas que usam a Bíblia como regra de fé, a saber, Judaísmo (tradicional e messiânico) e Cristianismo (católico, protestante e Testemunhas de Jeová), além da mais famosa tradução ecumênica atualmente disponível, ou seja, resultante de um consenso interconfessional que procura a unidade na diversidade, algo impensável e inexistente em um passado não muito remoto. Vejamos as versões que optamos por analisar:

1. Tradução do Novo Mundo das Escrituras Sagradas (1986) - doravante TNMES: tem as Testemunhas de Jeová como público alvo.

2. Tradução Ecumênica da Bíblia (1994) - doravante TEB: pretende ser utilizável por todos que usam a Bíblia como regra de fé. 
3. Tradução de João Ferreira de Almeida, edição corrigida e revisada (2006) - doravante TJFA: tem os cristãos protestantes como destinatários.

4. Bíblia Hebraica (2006) - doravante BH: feita por judeus tradicionais.

5. A Torah e a Berith Hadashah (2009) - doravante TBH: tem os judeus messiânicos como público alvo, ou seja, aqueles que acreditam ser Jesus de Nazaré o messias que viria ao mundo para redimir a humanidade.

6. Bíblia Judaica Completa (2010) - doravante BJC: seus destinatários também são os judeus messiânicos.

7. Tradução dos Monges Beneditinos de Maredsous (2010) - doravante TMBM: destinada aos cristãos católicos.

\section{As duas dimensões da Bíblia}

Os grupos religiosos que usam a Bíblia como texto fundador tendem a acreditar que ela, por ter sido revelada pela Divindade, tem relevância eterna e universal: fala para toda a humanidade, em todas as épocas e em todas as culturas. Gabel e Wheeler (2003, p. 223, 229-230) denominam tal crença de dimensão religiosa da Bíblia, apoiando-se na premissa de que, conforme eles próprios assinalam,

os livros bíblicos tiveram tanto um autor humano como um divino, [na] concepção do Judaísmo e do Cristianismo tradicionais. O autor humano empregou todos os seus recursos e toda a sua personalidade para compor a sua obra, mas foi tal o envolvimento da Divindade no processo que a obra pronta diz precisamente o que a Divindade queria que dissesse. E, com frequência, ainda segundo essa concepção, o que a Divindade desejava que a Bíblia dissesse era mais profundo ou mais abrangente do que o autor humano aparentemente dizia.

É provavelmente com base nesse ponto de vista que alguns acreditam existir determinadas passagens da Bíblia revestidas de dois sentidos: 1) o literal, que pode ser entendido por qualquer um que domine as línguas originais e conheça o antigo ambiente sociocultural de Israel e imediações; e 2) o mais que literal, ou seja, o sentido que transcende o literal, que costuma ter conotações místicas ou espirituais, pelo que Gabel e Wheeler (2003, p. 231) assumem que se costuma conceber esse segundo sentido como múltiplo. No entanto, conforme assinalam Geisler e Howe (1999, p. 23), apesar do status majoritariamente divino que os usuários da Bíblia costumam lhe atribuir, é preciso levar em conta que ela

não foi verbalmente ditada. Seus escritores não foram secretários do Espírito Santo. Eles foram autores humanos, que empregaram estilos literários próprios, com suas próprias idiossincrasias [...]. Esses autores humanos às vezes tomaram informações de fontes humanas para o que escreveram [...]. De fato, cada livro da Bíblia é uma composição feita por um escritor humano [...]. Esquecer-se da humanidade das Escrituras pode levar-nos a impugnar falsamente sua integridade por esperarmos um nível de expressão maior do que é o usual num documento humano. 
Deste modo, ao aceitarmos tal posição, fica claro que os livros que formam a Bíblia não surgiram em um passe de mágica. Pelo contrário, eles são acontecimentos discursivos que vieram a existir por intermédio de agentes e processos humanos, ou seja, de pessoas reais que viveram em contextos históricos concretos e específicos. Por conseguinte, a escrita dos livros foi condicionada e também influenciada pela linguagem, pela época, pela cultura, pelas formas literárias e pelos padrões de pensamento da sociedade em que surgiram. Gabel e Wheeler chamam esse outro lado, que está fora do âmbito religioso, e que é aqui exposto via os apontamentos de Geisler e Howe, de dimensão histórico-literária da Bíblia. Desse modo, parece que a ideia de que a Bíblia possui duas dimensões, uma religiosa e outra histórico-literária, permite que o entendimento de passagens escritas em tempos remotos não fique limitado ao entendimento das circunstâncias do período histórico em que surgiram os livros.

\section{Interpretar a Bíblia}

A maior diferença entre as comunidades religiosas que adotam a Bíblia certamente não está no cânone, ou seja, nos livros que devem ou não devem fazer parte do rol dos textos considerados sagrados. Pelo contrário, a principal diferença parece residir na maneira de interpretar os livros bíblicos que são comuns a todos os segmentos que tem essa obra como texto fundador. Esse pensamento é confirmado por Scholz (2006, p. 25), ao postular que as maiores divergências entre os grupos religiosos

dizem respeito a textos cuja canonicidade nunca foi posta em dúvida. [...] Dito de outra forma, mais importantes do que as divergências em torno da extensão do cânone são as diferenças de ordem hermenêutica, isto é, diferenças de interpretação de textos reconhecidamente canônicos.

Tendo delimitado o terreno, o próximo passo seria saber qual a maneira mais adequada de interpretar os livros da Bíblia. De acordo com Silva (2007, p. 14), de um lado,

existe o chamado "fundamentalismo", segundo o qual a Bíblia deve ser lida "ao pé da letra”, sem a necessidade de se estudar o universo em que ela surgiu. Para os fundamentalistas, o texto é claro por si mesmo e não condicionado pelo tempo, pela sociedade e pela história.

Porém, uma boa parcela dos estudos contemporâneos vai de encontro à ideia fundamentalista de interpretação da Bíblia. Por exemplo, Moura (2000, p. 29) postula que o método histórico-crítico (também chamado de exegese histórico-gramatical) é a forma mais adequada de interpretar essa obra. Scholz (2006, p. 8) diz que tal método consiste em decodificar o que está escrito levando em conta o momento histórico em que o texto surgiu. É válido mencionar que a função da exegese é tanto descobrir quanto avaliar o impacto do texto no ambiente original em que surgiu. A exegese, portanto, seria uma tarefa que está diretamente ligada à dimensão histórico-literária da Bíblia. No entanto, há uma outra tarefa que, tecnicamente, parece estar mais relacionada com a outra dimensão (a religiosa). Trata-se da hermenêutica, que se 
propõe a buscar a relevância contemporânea do texto. Conforme advertem Fee e Stuart (1997, p. 25-26),

a hermenêutica apropriada começa com a exegese sólida. O único controle apropriado para a hermenêutica acha-se na intenção original do texto bíblico. [...] Doutra forma, os textos bíblicos podem ser forçados a significar tudo quanto significam para qualquer determinado leitor. Semelhante hermenêutica, no entanto, fica sendo pura subjetividade, e quem, pois, vai dizer que a interpretação de uma pessoa é certa, e a doutra pessoa, errada? Qualquer coisa serve. Em contraste com semelhante subjetividade, insistimos que o significado original do texto - dentro dos limites da nossa capacidade para discerni-lo - é o ponto objetivo de controle.

Além disso, Fee e Stuart (1997, p. 13-14, 26) mencionam outra questão crucial, a saber, que

o alvo da boa interpretação não é a originalidade. Um texto não pode significar o que nunca significou. Não se procura descobrir aquilo que ninguém jamais viu. A interpretação que visa a originalidade pode ser atribuída a interesses escusos, por exemplo, à necessidade de apoiar um preconceito teológico. Interpretações desse tipo geralmente são equivocadas. Nos casos de interpretação imprópria, o erro está na sua hermenêutica, exatamente porque esta não é controlada pela boa exegese.

Ou seja, Fee e Stuart parecem estar defendendo que o intérprete ideal da Bíblia deve preocupar-se tanto com aquilo que o texto significava no contexto histórico de sua enunciação (exegese = dimensão histórico-literária) quanto com a relação de seu significado e intenção originais com sua relevância presente (hermenêutica = dimensão religiosa).

\section{Traduzir a Bíblia}

A Bíblia vem sendo traduzida desde os primórdios do Cristianismo. Hoje não restam dúvidas de que se trata do livro mais traduzido na história da humanidade. De acordo com Engler (2009, p. 232), essa obra já está disponível, no todo ou em partes, em quase 2500 línguas, e a quantidade de traduções aumenta a cada dia. Conforme observa Torre (2001, p. 17), se levarmos em conta que nenhuma outra obra, em nível mundial, conseguiu, durante tanto tempo, ser traduzida para tantas línguas e culturas, parece não haver problemas em considerar a Bíblia como ocupante de um lugar de primeiríssima ordem na história da tradução. Aliás, conforme observam Rothe-Neves e Gohn (2005, p. 136), “ao atravessar séculos sendo traduzida para diversas línguas, a Bíblia tornou-se para os estudiosos da tradução o que o iceberg é para os geólogos: um enorme registro de várias eras”.

Porém, traduzir a Bíblia é uma tarefa nada fácil. Segundo Konings (2009, p. 108-110), é preciso dominar não só as línguas de partida e de chegada, mas ter também o sensus linguae da relação entre os idiomas envolvidos no ato tradutório. E ele cita alguns exemplos disso que chama de sensus linguae:

Scientia Traductionis, $n .15,2014$ 
o grego bíblico não usa o optativo [...] e, sob influência das línguas semíticas, mistura o sentido de consequência com o de finalidade [...]. O status constructus hebraico e o genitivo grego estão abertos a inúmeras interpretações. Há as peculiaridades da sintaxe, da prosódia (que codetermina o sentido gramatical da frase), das construções retóricas. [...] O vocabulário bíblico é muito restrito e indica, pelo mesmo termo, realidades diferentes. E poderíamos alongar de muito a lista de peculiaridades que o tradutor deve levar em consideração.

Além de tais questões gramaticais, é digno de nota que a Bíblia contém escritos produzidos em contextos culturais e históricos que não estão mais presentes no meio cognitivo do público-alvo da tradução. A esse respeito, Rothe-Neves e Gohn (2005, p. 136) esclarecem o seguinte: "à medida que a tradução se separa do original pelo espaço geográfico e pelo tempo, os aspectos culturais mais específicos do texto de origem tornam-se mais facilmente distantes do público de chegada”. A consequência disso, também segundo Rothe-Neves e Gohn (2005, p. 135), é esta:

o texto traduzido é submetido a mudanças necessárias em vários níveis, em relação ao texto de partida. Essas mudanças não se devem apenas às diferenças linguísticas entre o polo produtor do texto de partida e o polo receptor da tradução, como se pensou durante muito tempo. Muitas dessas mudanças derivam do fato de que o texto traduzido ocupa, na cultura de chegada, um lugar específico e diferente daquele ocupado por textos originalmente produzidos nessa mesma cultura.

Ou seja, parece que o sentido original de um texto só pode ser entendido em suas múltiplas dimensões de significado à época de sua concepção, produção e publicação. Ao passar um texto de uma língua para outra, acontecem perdas e limitações naturais, pois todo acontecimento discursivo traz consigo determinadas especificidades e subjetividades tanto de ordem gramatical quanto de ordem cultural e histórica, as quais se perdem no processo tradutório.

\section{Análise das traduções de Isaías 7:14 e Zacarias 12:10}

Feita nossa contextualização teórica, passemos agora à análise de como as sete versões brasileiras da Bíblia que selecionamos traduziram duas passagens ditas messiânicas do AT.

\section{Isaías 7:14 e Mateus 1:23}

De acordo com Frye (2004, p. 107-109),

os escritores do Novo Testamento veem [...] o Antigo como uma fonte antecipadora dos eventos da vida de Cristo. Frequentemente, as antecipações são apontadas explicitamente, mencionando-se a origem precisa. [...] Outras vezes a relação permanece apenas implícita. [...] Tradicionalmente, formula-se o princípio geral da interpretação como "No Antigo Testamento, oculta-se o Novo; no Novo, revela-se o Antigo". Tudo o que acontece no Antigo Testamento é um "tipo", um esboço antecipador de algo que acontece no Novo [...]. O que se passa no Novo Testamento constitui um "antítipo", uma forma realizada, de algo prefigurado no Antigo. [...] Em 
suma, o Novo Testamento reivindica ser a chave para o Antigo, ou a explicação do que este quer realmente dizer.

Partindo desse princípio, os cristãos acreditam que em Isaías 7:14 está registrada a profecia de que o Messias nasceria de uma virgem, e que tal profecia se cumpriu na pessoa de Jesus de Nazaré, visto que o autor do evangelho de Mateus cita Isaías 7:14 na sua narrativa do nascimento de Cristo (Mateus 1:23). Com base nesse pressuposto, analisaremos como Isaías 7:14 e Mateus 1:23 foram traduzidas em nosso corpus. Vejamos, primeiramente, as traduções propostas para Isaías 7:14:

\begin{tabular}{c|l}
$\begin{array}{c}\text { TNMES } \\
\text { (1986, p. 844) }\end{array}$ & $\begin{array}{l}\text { Portanto, o próprio Jeová vos dará um sinal: eis que a } \\
\text { própria donzela ficará realmente grávida e dará à luz um } \\
\text { filho, e ela há de chamá-lo pelo nome de Emanuel. }\end{array}$ \\
\hline $\begin{array}{c}\text { TEB } \\
\text { (1994, p. 611) }\end{array}$ & $\begin{array}{l}\text { Pois bem, o SENHOR mesmo vos dará um sinal: eis que } a \\
\text { jovem está grávida e dá à luz um filho e lhe dará o nome de } \\
\text { Emanuel. }\end{array}$ \\
\hline $\begin{array}{c}\text { TJFA } \\
\text { (2006, p. 648) }\end{array}$ & $\begin{array}{l}\text { Portanto o mesmo Senhor vos dará um sinal: eis que a } \\
\text { virgem conceberá, e dará à luz um filho, e chamará o seu } \\
\text { nome Emanuel. }\end{array}$ \\
\hline BH & $\begin{array}{l}\text { Eis, pois, que o Eterno, Ele mesmo, vos dará um sinal: eis } \\
\text { que a moça grávida dará à luz um filho e o chamará } \\
\text { Imanuel ('Deus está conosco'). }\end{array}$ \\
\hline TBH & $\begin{array}{l}\text { Portanto, o mesmo YERRUA vos dará um sinal: eis que } \\
\text { uma jovem moça conceberá, e dará à luz um filho, e } \\
\text { chamará o seu nome Ymmanuel [conosco está Elohim]. }\end{array}$ \\
\hline (2009, p. 454) & $\begin{array}{l}\text { Portanto, o próprio ADONAI dará a vocês um sinal: a } \\
\text { jovem engravidará, dará à luz um filho e o chamará } \\
\text { Immanu El [Deus está conosco]. }\end{array}$ \\
\hline (2010, p. 503) & $\begin{array}{l}\text { Por isso, o próprio Senhor vos dará um sinal: uma virgem } \\
\text { conceberá e dará à luz um filho, e o chamará 'Deus } \\
\text { conosco'. }\end{array}$ \\
\hline TMBM
\end{tabular}

Agora vejamos como Mateus 1:23 foi traduzido em nosso corpus: 
TNMES

(1986, p. 1135)

TEB

(1994, p. 1857)

TJFA

(2006, p. 897-898)

TBH

(2009, p. 618)

BJC

(2010, p. 1220)

TMBM

(2010, p. 1285)
"Eis que a virgem ficará grávida e dará à luz um filho, e dar-lhe-ão o nome de Emanuel”, que quer dizer, traduzido: “Conosco está Deus.”

Eis que a virgem conceberá e dará à luz um filho, ao qual darão o nome de Emanuel, o que se traduz: "Deus conosco."

Eis que a virgem conceberá, e dará à luz um filho, e chamá-lo-ão pelo nome de EMANUEL, que traduzido é: Deus conosco.

Eis que uma moça jovem (betulá) conceberá, e dará à luz um filho, e chamá-lo-ão pelo nome de YMMÁNU’EL, que traduzido é: Elohim conosco.

A virgem conceberá e dará à luz um filho, e eles o chamarão Immanu El. (O nome significa: "Deus está conosco”.)

Eis que uma virgem conceberá e dará à luz um filho, que se chamará Emanuel (Is. 7:14), que significa: Deus conosco.

O primeiro quadro mostra que a TJFA e a TMBM utilizaram virgem em Isaías 7:14, ao passo que a TNMES se valeu de um termo com sentido análogo (donzela), enquanto que as demais versões empregaram vocábulos que variaram entre jovem e moça. Já o segundo quadro revela que todas usaram virgem na citação de Isaías 7:14 contida em Mateus 1:23, inclusive a TBH que, apesar de ter empregado moça jovem, interpolou no texto de chegada uma palavra hebraica que significa virgem (betulá). Em outras palavras, somente houve uniformidade textual entre AT e NT na TNMES (neste caso, implicitamente, tendo em vista que não optaram por virgem no AT, mas por donzela, de sentido paralelo), na TBH (neste caso, parcialmente, pois, apesar de constar "moça jovem" em Isaías e em Mateus, houve a interpolação do termo betulá em Mateus) e na TJFA e na TMBM (neste caso, explicitamente, já que o termo virgem aparece em ambas as passagens dessas duas versões). Diante dessa discrepância, dois questionamentos são inevitáveis:

1) Com relação ao texto traduzido: se os cristãos afirmam que Isaías $7: 14$ contém o prenúncio do nascimento virginal de Cristo, como explicar que o termo virgem nessa passagem aparece explicitamente apenas nos textos da TJFA e da TMBM, que, por sinal, são duas traduções que representam dois segmentos do Cristianismo, a saber, Protestantismo (TJFA) e Catolicismo (TMBM)? Teriam os tradutores dessas duas versões deturpado o sentido original do versículo, de forma que, fazendo o texto de 
Isaías concordar com o de Mateus, projetassem em suas traduções o efeito que gostariam que fosse suscitado no leitor?

2) Com relação ao texto original: considerando que em Mateus 1:23 o termo virgem está presente em todas as versões do nosso corpus (na TBH, implicitamente), seria isso um indicador de que o escritor desse evangelho tenha manipulado o texto de Isaías a fim de adaptá-lo à sua narrativa?

Para respondermos a essas perguntas, é necessário, em primeiro lugar, saber o que diz o texto original. No caso do primeiro quadro, o que está por trás das partes em itálico é almá, palavra hebraica ambígua que pode se referir a uma jovem ilibada (virgem) ou a uma jovem sem essa reputação. Gabel e Wheeler (2003, p. 218), quando discorrem sobre Isaías 7:14, além de reforçarem que o uso da palavra almá nem sempre acarreta que a mulher designada seja virgem, também observam que, na passagem em apreço, a palavra está em um contexto imediato que trabalha contra esse sentido, já que, conforme assinalam, parece ter sido utilizada por Isaías não para se referir a uma virgem no sentido moderno, mas a uma jovem na idade de se casar. Além disso, conforme lembra Weiss-Rosmarin (1996, p. 148), o hebraico possui uma palavra específica para designar uma virgem, a saber, betulá, fato que, à primeira vista, pode conduzir à conclusão de que o escritor do livro de Isaías poderia ter escolhido utilizar essa palavra se quisesse de fato se referir a uma jovem que não teve relações sexuais.

Já no segundo quadro, a palavra grega subjacente aos trechos em itálico é partenos, que possui significado unívoco, ou seja, virgem. Desse modo, seguindo a interpretação de Gabel e Wheeler, como o texto hebraico de Isaías dá a impressão de estar falando de uma "jovem”, ao passo que o texto grego de Mateus, quando cita esse profeta, fala explicitamente de uma "virgem", parece que temos aí um desacordo entre AT e NT. A propósito, conforme aponta Stern (2008, p. 30), Mateus 1:23 tem sido tema de uma grande controvérsia envolvendo céticos, judeus tradicionais e cristãos no que diz respeito à utilização de passagens do AT no NT. Mas, como veremos, há motivos razoáveis tanto para constar virgem na alusão ao livro de Isaías que aparece no texto grego de Mateus, quanto para a TJFA e a TMBM terem traduzido almá por virgem em Isaías 7:14.

Traçando as coordenadas espaço-temporais de Isaías 7:14 e devolvendo a passagem ao seu contexto histórico-literário, ela parece estar tratando da continuação da dinastia de Davi, famoso rei de Israel, da qual acredita-se que viria o Messias. Conforme Schökel (2002, p. 1701), o texto em questão estaria falando do nascimento do filho de Acaz, Ezequias, o qual futuramente subiria ao trono e daria continuidade à dinastia davídica. Também é importante observar que o texto menciona que a criança seria chamada de Emanuel, termo que, conforme pontua a TEB (1994, P. 611), parece ter sido empregado por Isaías não como nome próprio, mas como uma fórmula de aclamação litúrgica, já que não é atestado como nome pessoal em nenhuma parte do AT. Com isso, nota-se que o significado de Emanuel (Deus conosco) possui implicações em ambas as supostas esferas da Bíblia. No caso do ponto de vista histórico-literário, o aparato crítico de uma famosa tradução bíblica disponível 
atualmente, a Bíblia de Estudo Nova Versão Internacional (2003, p. 1148), assinala que o "Deus conosco" pode estar se referindo ao fato de que o profeta Isaías pretendia convencer Acaz de que o futuro rei que estava prestes a nascer por intermédio daquela almá seria auxiliado pela Divindade no tocante a livrar a nação israelita de todos os seus inimigos à época.

Por outro lado, olhando agora a passagem pelas lentes do que Gabel e Wheeler chamam de dimensão religiosa da Bíblia (cf. seção 2), o aparato crítico de uma outra famosa tradução bíblica disponível atualmente, feita pelo Pontifício Instituto Bíblico de Roma (1967, p. 886), registra que o termo Emanuel seria uma alusão à alegada Divindade do Messias que, quando viesse ao mundo, traria Deus para estar com os seres humanos. A propósito, a TEB (1994, p. 611) postula que, desde o século II a.C., e talvez antes disso, a tradição judaica, certamente levando em conta sua interpretação baseada no caráter profético de Isaías 7:14, viu nessa passagem o prenúncio do nascimento do Messias, personagem que acreditavam que viria ao mundo através de uma concepção milagrosa. Aliás, de acordo com Miguel (2007, p. 9), a própria passagem, quando fala que a Divindade dará um sinal (ôt, em hebraico) aos israelitas por intermédio do nascimento de uma criança, parece estar se referindo a algo fora do comum, pois, salvo raras exceções, a palavra ôt é sempre usada no AT para se referir a um acontecimento extraordinário.

Sendo assim, parece que a tradição judaica anterior à era cristã priorizou uma certa visão das coisas a partir de sua interpretação da dimensão religiosa e profética do texto bíblico quando traduziu pela primeira vez todo o AT para o grego (trabalho que viria a se chamar Septuaginta ${ }^{1}$ ), pois não traduziu almá como “jovem”, isto é, como tendem a traduzir as tradições judaicas posteriores à era cristã; ao contrário, verteu o termo por partenos, que significa virgem, como já explicitado. A propósito, conforme aponta o aparato crítico de uma outra famosa tradução bíblica, a Bíblia de Jerusalém (2002, p. 1265), a Septuaginta, que foi muito popular entre os judeus de Israel no século I d.C., é um precioso testemunho de como a tradição judaica antiga interpretava Isaías 7:14. Mais tarde, o escritor do evangelho de Mateus, segundo parece, entendeu que a mulher mencionada nessa passagem de Isaías tipificava, ou seja, prenunciava Maria, mãe de Jesus de Nazaré, tanto que, conforme esclarece Bruce (2011, p. 49), o texto de Isaías 7:14 citado em Mateus 1:23 é proveniente da Septuaginta, e não do original em hebraico.

Para continuar nossa discussão e a consequente análise do corpus, será necessário entrarmos agora em uma área que foge do estudo filológico do texto bíblico por estar mais relacionada ao campo da crença religiosa. A respeito desse segundo ponto de entrada, de acordo com Mettinger (2008, p. 15), a revelação divina transmitida à humanidade através da Bíblia pode ser comparada

1 A Septuaginta (“setenta”, em latim) é a tradução da Bíblia para o grego, feita pela comunidade judaica de Alexandria, no Egito, entre 275 a.C e 100 a.C., quando a Bíblia era composta apenas dos escritos que posteriormente seriam chamados de Antigo Testamento pelos cristãos. A Septuaginta também é conhecida por Versão dos Setenta, pois acredita-se que a parte considerada mais importante para a liturgia judaica (a Torah, que os cristãos costumam chamar de Pentateuco) foi traduzida por setenta rabinos judeus. 
com uma casa de dois andares, em que a parte da mensagem divina conhecida e compreendida pelos respectivos autores e profetas é o andar de baixo; a chave para o entendimento deste nível da Bíblia está, portanto, no estudo histórico e filológico dos textos. O andar de cima, pelo contrário, representa os arcanos ou "segredos" das intenções divinas, que podem ir muito mais longe do que um profeta particular afirmou sobre uma determinada situação histórica.

Dessa maneira, pode ser que o emprego do termo almá pelo autor do livro de Isaías tenha sido deliberado, pois, olhando através de um certo prisma religioso, notamos nesse versículo um possível jogo intrigante, proposital e intencionalmente ambíguo entre as duas supostas dimensões da Bíblia, em que a ambiguidade da palavra almá serve de ponte entre os dois planos. Ou seja, visto que o termo designa uma jovem não necessariamente virgem, ele pode servir, no primeiro plano, para anunciar um nascimento como qualquer outro (o de Ezequias). Já no segundo plano, a palavra pode servir para prenunciar o nascimento miraculoso do Messias, figura que a tradição judaica antiga provavelmente acreditava que viria ao mundo por intermédio de uma virgem, de sorte que os rabinos que produziram a Septuaginta verteram almá pela palavra grega que designa uma mulher nessas condições (partenos).

Como esse interessante jogo proporcionado pela ambiguidade de almá se perde no processo tradutório, a possibilidade de se levar em conta essas duas dimensões da Bíblia concomitantemente nesse trecho só pode ser potencialmente enxergada no texto original. Desse modo, caso tenham tomado consciência de tais implicações, talvez os tradutores tiveram de decidir à qual das duas dimensões dariam prioridade. No que diz respeito ao nosso corpus, percebe-se que a TNMES, a TEB, a $\mathrm{BH}$, a TBH e a BJC parecem ter priorizado o contexto histórico-literário, enquanto que a TJFA e a TMBM deixaram uma possível interpretação da dimensão religiosa da Bíblia prevalecer no texto traduzido.

Para finalizar, voltemos ao segundo quadro, atentando agora para a TBH. Como vemos, o comportamento dessa Bíblia com relação a Mateus 1:23 foi inusitado. Enquanto que nas demais consta virgem nessa passagem, na TBH aparece a expressão moça jovem com o termo hebraico betulá interpolado, que, como já vimos, designa especificamente uma virgem. Mas, infelizmente, o paratexto dessa Bíblia não traz esclarecimento algum sobre o que levou os tradutores a agirem dessa maneira, de modo que tudo que nos propusermos a dizer sobre tal atitude não irá muito além da especulação.

\section{Zacarias 12:10}

Vejamos a tradução interlinear desta passagem, que tomamos da edição de Kohlenberger III (1987, p. 579-580) do AT:

E derramarei sobre [a] casa de Davi e sobre o habitante de Jerusalém [um] espírito de graça e súplicas "e eles olharão para mim a quem eles traspassaram" e eles lamentarão por ele como lamentam pelo filho único e prantearão amargamente por ele como pranteiam amargamente pelo primeiro filho nascido. 
A interpretação cristã tradicional para esse acontecimento discursivo profético é a de que a Divindade está declarando, em um primeiro momento (a parte entre aspas), que ela própria será traspassada pela morte do misterioso mártir inocente e anônimo que enviará, pela qual o próprio povo de Israel seria responsável. É interessante notar que o começo da frase não faz distinção entre a Divindade e esse personagem, o que de fato só acontece na continuação (parte em itálico). Considerando as coordenadas espaço-temporais da passagem, Schökel (2002, p. 2303) observa que esse mártir pode ter sido o rei Josias, visto que Zacarias 12:11 diz que haveria grande luto em Jerusalém com a morte do traspassado, assim como houve no vale do Megido, onde, conforme II Reis 23:29, Josias foi morto. É claro que isso pode ser uma mera coincidência, afinal, considerando-se a expectativa de vida das pessoas àquela época, bem como a necessária morte dos nobres, de quando em quando não tão distantes no tempo, não haveria escassez de figuras a quem atribuir ou relatar luto de grande monta.

Já no âmbito religioso, o enigmático personagem tem sido identificado com a figura do Messias não só pelos cristãos, mas também pela tradição judaica antiga. Para os cristãos, a profecia de Zacarias 12:10 foi cumprida na pessoa de Jesus de Nazaré, visto que o escritor do evangelho de João cita essa passagem quando narra que o nazareno teve as mãos e os pés atravessados pelos cravos e o lado perfurado pela lança do soldado romano ao ser executado por crucificação (João 19:37). Para nossa análise, interessa-nos o trecho entre aspas da tradução interlinear de Zacarias 12:10. Vejamos como nosso corpus o traduziu:

\begin{tabular}{|c|c|}
\hline $\begin{array}{c}\text { TNMES } \\
(1986, \text { p. } 1127)\end{array}$ & ...olharão para Aquele a quem traspassaram... \\
\hline $\begin{array}{c}\text { TEB } \\
(1994, \text { p. } 989)\end{array}$ & $\begin{array}{l}\text { Erguerão, então, o olhar para mim, aquele a quem } \\
\text { traspassaram. }\end{array}$ \\
\hline $\begin{array}{c}\text { TJFA } \\
(2006, \text { p. } 867) \\
\end{array}$ & ...e olharão para mim, a quem traspassaram... \\
\hline $\begin{array}{c}\text { BH } \\
\text { (2006, p. 608) }\end{array}$ & $\begin{array}{l}\text {...e olharão para Mim por causa daqueles que foram } \\
\text { traspassados... }\end{array}$ \\
\hline $\begin{array}{c}\text { TBH } \\
\text { (2009, p. 614) }\end{array}$ & ...e olharão para mim, a quem traspassaram... \\
\hline $\begin{array}{c}\text { BJC } \\
(2010, \text { p. } 815) \\
\end{array}$ & ...e eles olharão para mim, a quem traspassaram... \\
\hline $\begin{array}{c}\text { TMBM } \\
(2010, \text { p. } 1278)\end{array}$ & $\begin{array}{l}\text {...voltarão os seus olhos para mim. Farão lamentações } \\
\text { sobre aquele que traspassaram... }\end{array}$ \\
\hline
\end{tabular}

$\mathrm{O}$ quadro mostra que a TNMES e a $\mathrm{BH}$ desviaram-se da discursividade original, pois no texto de chegada dessas Bíblias a Divindade está afirmando que o traspassado é um outro personagem. Conforme Miguel (2007, p. 14), uma tradução dessa natureza não encontra apoio na gramática do hebraico bíblico. Antes de 
entrarmos nos motivos que ele apresenta, consideremos primeiramente a transliteração e a tradução literal do excerto:

Vehibitú (e eles olharão) elay (para mim) êt (indicação de objeto direto) asher (que) dakarú (eles transpassaram) vesf'rú (e prantearão) aláiv (sobre ele) k’mispêd (lamento).

Ao discorrer sobre a tradução proposta pela BH, Miguel (2007, p. 14) observa que

o uso de "êt" pelo tradutor foi totalmente ignorado. O "êt" tem a função de indicar objeto direto em uma oração, ou seja, que a estrutura após o "êt" recebe a ação do sujeito da estrutura anterior. "Eles" (os que olharão) são os sujeitos da oração. "Eles olharão” para aquele (“... para mim...”) que "eles transpassaram” e chorarão. Não há como sustentar "aqueles que foram transpassados", até porque o verbo transpassar "dakarú” está na voz "Qal”, ou seja, voz ativa e não voz passiva. Indicado "ação sobre” e não que os sujeitos da oração estão recebendo a ação.

Sendo assim, Miguel conclui que, na $\mathrm{BH}$, a atitude dos tradutores indica uma possível tentativa de ofuscar o lamento sobre o Messias ferido pelas iniquidades de Israel e das nações. E parece que esse efeito se dá de fato, pois os recursos que utilizaram alteraram o que podemos chamar de frase-chave da passagem profética, pois no texto de chegada da $\mathrm{BH}$ está dito que a Divindade será vista não porque foi traspassada, mas por causa daqueles (os israelitas?) que foram traspassados.

Já no que diz respeito à TNMES, certamente foi outro o motivo que levou os tradutores a se desviarem da discursividade original, pois as Testemunhas de Jeová (doravante TJs), ao que parece, acreditam que Cristo é o Messias. Isso, inclusive, está dito em uma das suas principais publicações doutrinárias: “O cumprimento das profecias bíblicas e o testemunho do próprio Jeová mostraram claramente que Jesus era o Messias prometido."2 Isto quer dizer que há um outro motivo que levou os tradutores a abandonarem a discursividade da passagem. Tal motivo está ligado ao fato da descrença das TJs em um dogma tradicional do Cristianismo, a saber, que Jesus é Deus encarnado. Sendo assim, o que parece estar em jogo em Zacarias 12:10 é justamente a alegada Divindade de Cristo, pois, contrariando a tradição cristã, como dito, as TJs não creem que Jesus seria a encarnação da Divindade, mas a da sua primeira criatura (o arcanjo Miguel), conforme declarado em seus dois principais periódicos ${ }^{3}$ :

Jesus, diferentemente de qualquer outro humano, viveu no céu como pessoa espiritual antes de nascer na Terra. (João 8:23) Ele foi a primeira criação de Deus e ajudou a criar todas as outras coisas. [...] Ele é o único que foi criado diretamente por Jeová e, por isso, é chamado de Filho "unigênito" de Deus. [...] Por ter sido criado, Jesus não faz parte de uma Trindade. [...] Ele mostrou que não era um anjo

2 O que a Bíblia realmente ensina? (2005, p. 40).

3 Quem são as Testemunhas de Jeová? Revista Despertai!, agosto de 2010, p. 8. O homem que mudou o mundo: sua mensagem e você. Revista $A$ Sentinela, $1^{\circ}$ de abril de 2010, p. 5,19. O que são as "boas novas do reino?” Revista A Sentinela, $1^{\circ}$ de março de 2011, p. 16. 
materializado, nem Deus em forma humana. Em vez disso, ele era completamente humano. [...] Jesus serviu como Porta-Voz de Deus e, por esse motivo, é também chamado de "a Palavra”. [Além disso], Jesus Cristo é o arcanjo Miguel. É importante notar que o nascimento de Jesus como humano não foi o início de sua vida. Durante seu ministério, Jesus muitas vezes falou de sua existência pré-humana. - João 3:13; 8:23,58. Portanto, o arcanjo Miguel é Jesus em sua existência pré-humana.

Dessa maneira, percebe-se que Zacarias 12:10 parece ser uma pedra de tropeço para as TJs, pois consta no texto original dessa passagem que a própria Divindade declara a si própria atingida pela morte do seu enviado, o qual é identificado pelas TJs com o Messias, também reconhecido por elas na pessoa de Jesus de Nazaré. Destarte, como o texto parece conter uma afirmação implícita da Divindade do Messias, isso traz dificuldades à crença desse grupo religioso, pois, como acabamos de ver, elas acreditam que Cristo é a encarnação não de Deus, mas do seu primeiro ser criado, o arcanjo Miguel. Por conseguinte, parece que a solução que os tradutores encontraram foi deixar de lado a discursividade original e distinguir Deus do personagem identificado com o Messias em toda a frase, distinção essa que o original faz apenas na parte em itálico.

\section{Considerações finais}

Se olharmos pelo prisma de que a Bíblia, como texto religioso, possui uma dimensão histórica e uma dimensão transcendental, como defendem alguns autores, ficará mais fácil de perceber que há determinadas passagens em que parece existir uma espécie de entrelaçamento entre essas duas dimensões. Cremos que essa ideia ficou evidente com a investigação aqui feita, pois percebe-se que as passagens que analisamos, em um primeiro momento, dizem respeito a acontecimentos discursivos específicos situados no tempo e no espaço, e, em um segundo momento, elas podem estar se referindo a eventos de natureza religiosa-transcendental. Partindo dessa perspectiva, para aqueles que defendem o uso racional da Bíblia, parece sensato, bem como necessário, buscar um equilíbrio entre as duas supostas dimensões dessa obra, procurando não superestimar nenhuma das duas, já que, dentro do ponto de vista aqui defendido, uma parece depender da outra.

Assim, entendemos que há uma certa legitimidade nas alegações cristãs de que as duas passagens aqui analisadas podem, em uma dimensão metafísica, estar se referindo ao fundador dessa religião. Mas é óbvio que essa ideia, por estar mais relacionada ao campo da crença religiosa, não pode ser plenamente captada pelo estudo filológico do texto bíblico. Apesar disso, ela não deixa de poder ser válida e parece estar bem presente entre os grupos religiosos que usam a Bíblia, especialmente os de matriz cristã, pois, conforme acreditamos ter conseguido demonstrar com a análise do nosso corpus, o suposto entrelaçamento das duas dimensões, que acontece de forma implícita, é verdade, pode muitas vezes ser perdido em uma Bíblia traduzida, em que a perda algumas vezes é inevitável, em virtude da própria natureza do processo tradutório, como vimos nas traduções propostas para o termo hebraico almá, em Isaías 7:14, e outras vezes é proposital, para atender a um determinado posicionamento 
teológico, como foi demonstrado mediante a análise comparativa das traduções de Zacarias 12:10.

Marcelo Raupp

mrraupp@yahoo.com.br Doutorando, Universidade Federal de Santa Catarina

\section{Referências bibliográficas}

A Sentinela. Anunciando o Reino de Jeová. O homem que mudou o mundo: sua mensagem e você. Cesário Lange: Associação Torre de Vigia de Bíblias e Tratados, $1^{\circ}$ de abril de 2010.

O que são as Boas Novas do Reino? Cesário Lange: Associação Torre de Vigia de Bíblias e Tratados, $1^{\circ}$ de março de 2011.

BíBliA. A Torah e a Berith Hadashah. [S.l.: s.n.], 2009. Bíblia Apologética de Estudo. Tradução de João Ferreira de Almeida. 2. ed. Jundiaí: Instituto Cristão de Pesquisas, 2006. Edição Almeida Corrigida e Revisada.

Bíblia de Estudo Nova Versão Internacional. São Paulo: Editora Vida, 2003. Bíblia de Jerusalém. Tradução de Euclides Martins Balancin et al. São Paulo: Paulus, 2006.

Bíblia Hebraica. Tradução de David Gorodovits e Jairo Fridlin. São Paulo: Sêfer, 2006.

Bíblia Sagrada: Edição Pastoral Catequética. Tradução dos Monges Beneditinos de Maredsous. São Paulo: Ave Maria, 2010.

Bíblia Sagrada: Tradução dos textos originais, com notas, dirigida pelo Pontifício Instituto Bíblico de Roma. São Paulo: Edições Paulinas, 1967.

Tradução do Novo Mundo das Escrituras Sagradas. Cesário Lange: Sociedade Torre de Vigia de Bíblias e Tratados, 1986.

Tradução Ecumênica da Bíblia (TEB). São Paulo: Edições Loyola, 1994.

BRUCE, F. F. O cânon das Escrituras: como os livros da Bíblia vieram a ser reconhecidos como Escrituras Sagradas? Tradução: Carlos Osvaldo Pinto. São Paulo: Hagnos, 2011. Tradução de: The canon of Scripture.

DesPerTAI! Quem são as Testemunhas de Jeová? Cesário Lange: Associação Torre de Vigia de Bíblias e Tratados, agosto de 2010.

ENGLER, Steven. Translation, tradition and the eternal present of the sacred text. In: A Bíblia e suas traduções. São Paulo: Humanitas, 2009, p. 225-241. 
FeE, Gordon D.; StuART, Douglas. Entendes o que lês? Um guia para entender a Bíblia com auxílio da exegese e da hermenêutica. São Paulo: Vida Nova, 1997. Tradução de: How to read the Bible for all its worth: a guide to understand the Bible.

Frye, Northrop. O Código dos Códigos: a Bíblia e a Literatura. Tradução: Flávio Aguiar. São Paulo: Boitempo, 2004. Tradução de: The Great Code: the Bible in Literature.

Gabel, John B.; Wheeler, Charles B. A Bíblia como literatura. Tradução: Adail Ubirajara Sobral e Mana Stela Gonçalves. São Paulo: Edições Loyola, 1993. Tradução de: The Bible as literature.

GeISleR, Norman L.; Howe, Thomas. Manual popular de dúvidas, enigmas e “contradições” da Bíblia. Tradução: Milton Azevedo Andrade. São Paulo: Mundo Cristão, 1999. Tradução de: When critics ask: a popular handbook on Bible difficulties.

KoHlenBerger III, John R. The Interlinear NIV Hebrew-English Old Testament. Michigan: Zondervam Publishing House, 1987.

Konings, Johan. Tradução e traduções da Bíblia no Brasil. In: A Bíblia e suas traduções. São Paulo: Humanitas, 2009, p. 103-126.

Mettinger, Tryggve N. D. O significado e a mensagem dos nomes de Deus na Bíblia. Tradução: Daniel Sotello. Santo André: Academia Cristã, 2008. Tradução de: The meaning and message of the Everlasting Names.

Miguel, Igor. Problemas da Bíblia hebraica em português: alterações textuais que impedem a percepção de Yeshua como o Messias. Disponível em $<$ http://goo.gl/LxaKvS>. Acesso em 04 novembro 2010.

MourA, Jaime Francisco de. As diferenças entre: Igreja Católica e Igrejas Evangélicas. São José dos Campos: COMDEUS, 2000.

O Que A Bíblia Realmente Ensina? Cesário Lange: Sociedade Torre de Vigia de Bíblias e Tratados, 2009. Tradução de: What does the Bible really teach?

Rothe-Neves, Rui; GoHn, Carlos Alberto. Mutações no sagrado: o antijudaísmo em traduções do Novo Testamento. In: Estudos judaicos: ensaios sobre literatura e cinema. Belo Horizonte: Faculdade de Letras, UFMG, 2005, p. 135-144.

SchöKel, Luís Alonso. Bíblia do Peregrino. Tradução: Ivo Storniolo, José Bortolini e José Raimundo Vidigal. São Paulo: Paulus, 2002. Tradução de: Biblia del Peregrino: Edicion de Estudio.

Scholz, Vilson. Princípios de interpretação bíblica: introdução à hermenêutica, com ênfase em gêneros literários. Canoas: Editora da ULBRA, 2006.

SIlva, Cássio Murilo Dias da. Leia a Bíblia como literatura. São Paulo: Edições Loyola, 2007.

STERn, David H. Bíblia Judaica Completa: o Tanakh [AT] e a B'rit Hadashah [NT]. Tradução: Rogério Portella e Celso Eronides Fernandes. São Paulo: Editora Vida, 2010. Tradução de: Complete Jewish Bible.

TORRE, Esteban. La traducción: concepto e evolución histórica. In: Teoria de la traducción literaria. Barcelona: Editorial Sintesis, 2001.

Weiss-Rosmarin, Trude. Judaísmo e Cristianismo: as diferenças. Tradução: Sílvia Waldsztejn. São Paulo: Sêfer, 1996. Tradução de: Judaism and Christianity: the differences. 